\title{
CHRONOLOGY OF WOMAN SUFFRAGE MOVEMENT IN
} IOWA

The movement for the enfranchisement of woman first found place in Iowa's legislative journals in 1866 , when the General Assembly ordered an inquiry as to the expediency of striking out the word "male" from the state constitution. Two years later steps were taken looking toward the proposed change. In 1870 the battle seemed won! Then began a notable series of seesaws between the two houses. In 1878 both houses indefinitely postponed the proposed amendment. The battle now seemed lost! In 1880 women were given a vote on expenditure of money for school buildings, etc. In 1882 the legislature was for the amendment; in 1884 it would do nothing. In 1886 and in 1888 the seesaw was resumed, and the subject was treated as a joke. Complimentary but unmeaning votes followed until 1913, when both houses passed the measure, the Senate by sixteen and the House by fifty-five majority! With this strong endorsement, from the Thirty-fifth General Assembly, the Thirty-sixth carly took up the question and passed the amendment on to the voters of Iowa. A suffrage amendment was presented to voters at the primary election in June, 1916, and was voted down by a majority of over 10,000 .

Before passing to other themes, mention should be made of the pioneer women of Iowa, prominent among whom were Mrs. Savery, Mrs. Bloomer, Mrs. Callanan, Mrs. Coggeshall, Mrs. Cattell and Mrs. Wright, who in their respective personalities refute the assertion that no true, womanly woman wants the suffrage. These bore aloft the banner of equal suffrage when their cause throughout the nation was the object of rude assault and unmanly ridicule. None of them lived to see the fruition of their hopes; but every one of them died in the confident expectation that it would not be long delayed. With the defeat of the amendment, the suffragists bravely inaugurated a movement for the resubmission of the amendment.- "Iowa, It's History and It's Foremost Citizens," page 653, by Johnson Brigham. 
Copyright of Annals of Iowa is the property of State of Iowa, by \& through the State Historical Society of Iowa and its content may not be copied or emailed to multiple sites or posted to a listserv without the copyright holder's express written permission. However, users may print, download, or email articles for individual use. 